Any conclusion reached on the nature of the Apostasy in Hebrews must be tentative, in view of our uncertainty as to the document's date and destination. The balance of the evidence would suggest that the readers were Jewish Christians, who were tempted to return to Judaism instead of advancing to Christian perfection. There seems no very grave objection to the recent suggestion that they were the company of priests in Acts vi.7, or even that they emanated from Qumran. They may even have hoped, as the true sons of Zadok, to establish themselves in the Temple at Jerusalem when the day of A.D. 70 actually dawned.

For ourselves, however, the warnings about drawing back and flinging away our Christian reward remain as pertinent as ever. Though Judaism may exercise none of its ancient fascination for the Christian Church, she will never be short of the faint-hearted and the backsliding, nor of those who shirk the responsibility of teaching. The age-long peril of apostasy will be countered only by the age-old practice of this inspired writer:

'By looking unto Jesus, the author and perfecter of our faith.'

\title{
Tertullian on Prayer
}

\section{by Dr. O. W. Holmes}

THE FACT that the Tyndale Fellowship exists "for Biblical Research" is not intended to restrict the interests of its members to a narrow interpretation of the phrase, as is evidenced by the existence of its Church History Group, which yields evidence of light shed down the ages by those who have found in our Scriptures the source of their message to their day and age.

We have, in the Church of Carthage of Tertullian's day, almost a perfectsubject for the detached study of the place which prayer occupied, or should occupy, in a church whose very founder (if it had one) we do not know, living close (but not too close) to the cradle of the Christian faith in both time and place, as seen through the eyes of a man originally a member of 
the "great Church", and yet identified with that late upsurging of the prophetic impulse associated with the name of Montanism.

As far as Tertullian's personal history is concerned there has been speculation in plenty, but really there is not a great deal known. St. Jerome tells us ${ }^{1}$ that Tertullian's father exercised an office of proconsular centurion: we can see for ourselves that Tertullian had reached a mature age by the date when the Apologeticum was written (A.D. I87) and he tells us himself that he had once jested at Christians, frequented the Spectacles and otherwise played the pagan. He was a married man; as to whether he was a priest of the Catholic Church much writing even now has not fully reconciled divergences of view. We shall find that Tertullian's beliefs did not, contrary to the assumptions of some, undergo any greater change than that often to be found in the writings of a man who is before the public for two or three decades ${ }^{2}$, but historical accident caused him to part from the Catholics, so that views he may have hesitated to express openly in his earlier writings are recorded without restraint when he had left their Church. Speak of him how we will, there is something of the heroic (in its finer sense) in the spectacle of a man from the cultured levels of the world of his day espousing a cause mainly identified with the unprivileged, and standing forth fearlessly as the Christians' champion, without question risking his own position and his own life for the sake of his new brethren.

The most superficial reading of Tertullian's works will show how largely his thinking and his arguments for convincing his opponents rest upon Scripture. We are explicitly told in one of Tertullian's early writings that he regards the Old Testament writings as divinas ${ }^{3}$, and that the Holy Spirit has instructed the prophets in the truths of salvation ${ }^{4}$ : there is no reason to suppose that these views suffered any change over the years during which he wrote. The New Testament is bracketed with the Old in standing ${ }^{5}$, indeed it is the fruit of which the Old

${ }^{1}$ De viris illustribus LIII.

2 This is a study in itself.

3 Apol. xx.

- Apol. xviii.

s De Prae. Her. xxxvi. 
Testament is the seed ${ }^{6}$. Tertullian's range of quotations is broadly based, and of our canonical books he employs all but Ruth, Esther and Haggai. For the Old Testament the Septuagint version was his stand-by; in quoting the New Testament he employs his own translation from the Greek, or an extant Latin version, at will. In the employment of Scripture as warrant for his views he set himself the standard: pauca multis, dubia certis, obscura manifestis adumbrantur ${ }^{7}$. In short, his basis was broad, and his principles of interpretation were sound.

The sufferings of the Scillitan martyrs (A.D. I80) were apparently followed in Africa by a period of calm for the Christians, but this would be precarious, and liable to interruption at the whim of the governor. There must surely have been martyrs about the year 197 to justify the ad Martyras, and again to call forth the ad Scapulam in 212. Such happenings explain much of the frequently burning vigour of Tertullian's style, and unless we keep in mind considerations of this sort we shall not enter into the circumstances in which his teaching on any subject, prayer included, came to be given. His own words on the efficacy of persecution to quicken spiritual life come from the lips of a man who knew what he was talking about ${ }^{8}$.

One of the themes for which the writings of Tertullian may with profit be studied is the place of prayer in the life of the Church at that point. From the writings of some we might be tempted to conclude that little but formal liturgies could be found in the corporate worship of the early Church. There are more than two hundred passages in which Tertullian treats of prayer. He uses in all about seventy different turns of phrase (in the Latin) in relation to prayer. Apart from the frequent, and relatively colourless, orare and oratio, he uses (notably in his later writings) adorare on nineteen occasions and exorare, with its thought of prevailing in prayer, eleven times. Study of the incidence of his terms will show that prayer is represented not only as a duty but also as a right - postulare occurs 34 times, more frequently as the years succeed. Prayer meditative and mysticism are not found frequently, but Tertullian is clearly

- Adv. Marc, vi II.

'De Pud. xvii. al.

- "Than when is trust in God more strong ... than when persecution breaks out? . . . better disciplined in fasts, in prayers ..." De Fuga i. 
attracted to the idea of prayer as the natural fellowship of friend with Friend. He employs loqui, the easy talk of one with another, and describes Abraham as vir divinae familiaritatis ${ }^{9}$.

Tertullian is known to have written forty-three treatises, of which we are fortunate enough to possess thirty-one; of the others we have knowledge in most cases from references in extant works. No doubt some of these lost works would add something to our knowledge of Tertullian's views, particularly his de Ecstasi, which Jerome tells us ${ }^{10}$ had seven parts. This aside, the early years of the present century saw virtual agreement on the order in which Tertullian's surviving works had been written, and our remaining space shall be devoted to giving, in chronological order, the main aspects of his treatment of prayer in some of the more important treatises from this point of view. There are over 220 passages in which he throws light on prayer, and the figures given in parentheses show the number of passages in the work cited:

A.D. I97 Apologeticum ( 18 ) - Pagan prayer is portrayed as widespread, but as external rather than sincere, external in its manifestations as well as in the benefits it seeks. In sharp contrast to this, Christian prayer is earnest; it is rightly based, both as regards its destination and its entitlement; and it has for a main thesis the well-being of the Emperor.

197-200 De Testimonio Animae (5) - The unstudied ejaculatory prayer of the pagans is testimony to the existence of a supreme God, above the lesser godlings who are by custom addressed. The pagans also think to work good or ill to the dead by invocations or imprecations.

200 De Spectaculis (2) - Attendance at the Spectacles not only puts prayerful thoughts out of the mind at the time, but forms a wholly incongruous sequel to corporate prayer. 200-6 De Oratione (29) - The first nine chapters centre round the Lord's Prayer, its Divine preceptor, its comprehensiveness in worship, in submission, in petition. The treatise then broadens out to a review of inward hindrances to prayer, and of sundry outward observances; and finds its conclusion in a quite lyrical exaltation of Christian prayer and its efficacy.

${ }^{9}$ De Res. Carn. xviii.

10 De viris illustribus LIII. 
200-6 Adversus Iudaeos (5) - The faithfulness in prayer of a Moses or a David is sharply contrasted with the futility of contemporary Jewish prayer. The real successors to those who reached great heights of prayer in Old Testament times are not the Jews of Tertullian's day, but those, of every nation, who now invoke Christ.

(206) De Virginibus Velandis (4) - The gravamen of his charge against the virgin unveiled at prayer is the irreverence and audacity before God this displays at a time of special solemnity.

$(208-I I)$ Adversus Marcionem $I-V(42)$ - At this point we enter on the period of the established writer turning his attention to the more profound aspects of the faith, not excepting the place of prayer in such deeper thinking. It is most regrettable that so little attention has hitherto been given to these important writings. In Book One Tertullian speaks of the universality of prayer to God, the rational basis of such thought, and the fitness of prayer directed to the source of all good gifts. In Book Two reverence is postulated, and God is shown as (logically, in view of His nature) guiding the course of history so that man might attain to intercourse with Him: "God held converse with man, that man might learn to act as God"11. And as against Marcion's teaching that for God to change His purposes following prayer was unworthy of Godhead and hence to be dismissed, Tertullian rises high to show that these changes of purpose are but tactics in a broad strategy of raising men to fellowship with God. Book Three cites Old Testament examples of the types under which this purpose of God was concealed - concealed intentionally, the better to evoke man's sense of need and cause him to cry for aid. Book Four is concerned to show that the Old Testament is of a piece with the New, in its teaching on prayer as in other realms. Book Five is for our purpose less relevant, but it does speak of the access to the Father won for man by Christ.

(208-II) De Resurrectione Carnis (II) - With the eternal verities of the bliss hereafter in view, the Christian naturally prays for the end of this world; in the after-life there is both ${ }^{11}$ Adv. Marc, ii. 27. 
prayer and praise, with continuity in both cases from the life beyond death.

(Post 213) Adversus Praxean ( 8 ) - The error of Praxeas caused Tertullian to distinguish between the persons of the Trinity and, consequentially, to distinguish between their roles in relation to prayer. The Son, he says, is $\mathrm{He}$ who in the Old Testament Theophanies trained men in Divine discourse; the Son when on earth was distinct Person (as when $\mathrm{He}$ prayed to the Father in heaven); and His prayer for the Comforter to be sent shows the third Person of the Trinity to be distinct too.

(2I 7-22) De Pudicitia (I2)-In this treatise the place of prayer in relation to the remission of sins of others is considered; the case of Jeremiah and the words of John are reviewed as showing that there is a limit to such intercession. And the abuses attending intercessory prayer in Tertullian's day are denounced. On the other hand, he considers that we rightly pray that venial sins be pardoned.

There is a vast amount more that Tertullian has for us in this great theme of prayer - the philosophy of prayer, its theology and its practice, but perhaps the foregoing paragraphs will have served as an introduction to a field that has rich ore for those who will mine there.

\section{The Altar in Foshua and Fudges* by J. P. U. LILLEY}

THE OBJECT of this paper was to study the evidence in the text on Israelite methods of building altars, and to consider what were the differences from Canaanite custom. Little is said directly in the text. The Law (Ex. xx. 24ff.) prescribes earth or rough stone altars, with the intention that they should be temporary, just as the earth filling of the tabernacle altar would leave no permanent memorial; this is borne out by the facts stated or implied in Judg. $\mathrm{xx}-\mathrm{xxi}$, while the permanent 'altars' on Ebal (Josh. viii. 3off.) and by Jordan (Josh. xxii. ro) were for different purposes.

* Summary of a paper read at the O.T. Study Group, July 1959 